\title{
Control of Nitrogenase Synthesis in Klebsiella pneumoniae
}

\author{
By R. S. TUBB AND J. R. POSTGATE \\ A.R.C. Unit of Nitrogen Fixation, University of Sussex, Falmer, \\ Brighton, BNI $9 Q J$
}

(Received 18 March 1973; revised 6 June 1973)

SUMMARY

Sulphate-limited continuous cultures of Klebsiella pneumoniae showed a proportional repression of nitrogenase activity with increasing concentrations of ammonium ion in the influent medium. A fully repressed population had a $50 \%$ greater bacterial density than a fully derepressed one. On derepression, synthesis of nitrogenase lagged for $90 \mathrm{~min}$ after exhaustion of $\mathrm{NH}_{4}{ }^{+}$from the medium but was complete within one doubling time. Casamino acids did not decrease the prefixation lag obtained under sulphate-limited conditions in the chemostat. Longer lags were obtained when $\mathrm{NH}_{4}{ }^{+}$was exhausted under $\mathrm{N}$-limited conditions. Such lags were decreased by Casamino acids, yeast extract, or L-aspartate. Aspartate-N completely repressed nitrogenase under sulphate- or carbon-limited conditions but not under nitrogen limitation. In the initial stages of repression of nitrogenase synthesis by $\mathrm{NH}_{4}^{+}$, apparent production of active enzyme continued for a short time in the absence of protein synthesis de novo; nitrogenase was then diluted out as the organisms multiplied. Repression by $\mathrm{NH}_{4}{ }^{+}$was at the level of mRNA transcription according to studies with rifampicin and chloramphenicol. 'Coding capacity' for nitrogenase synthesis declined with a half-life of about $4.5 \mathrm{~min}$ following inhibition of RNA synthesis with rifampicin. $\mathrm{NH}_{4}{ }^{+}$did not influence the decay rate but stimulated translation of such nitrogenase-specifying $\mathrm{mRNA}$ as had been initiated.

\section{INTRODUCTION}

The regulation of nitrogenase synthesis by sources of fixed nitrogen in Azotobacter chroococcum in continuous culture was described by Drozd, Tubb \& Postgate (I972). In Azotobacter, derepression of nitrogenase followed rapidly once $\mathrm{NH}_{4}{ }^{+}$became exhausted from the medium. Nitrogenase activity was detected immediately (Drozd et al. 1972) or after a delay of up to I h (Strandberg \& Wilson, I968; Shah, Davis \& Brill, 1972) depending upon growth conditions. In Klebsiella pneumoniae, Pengra \& Wilson (I958) found no significant ${ }^{15} \mathrm{~N}_{2}$ incorporation during the period immediately following exhaustion of $\mathrm{NH}_{4}{ }^{+}$. Inductive lags of $13 \mathrm{~h}$ (Mahl \& Wilson, I968) and I5 h (Lindsay, I963) have been reported. Yoch \& Pengra (1966) observed a diauxic growth lag of about $2 \mathrm{~h}$ after exhaustion of limiting $\mathrm{NH}_{4}{ }^{+}$. This shorter lag could have arisen from the use of nitrogen-fixing organisms as inocula because the length of such a lag in Clostridium pasteurianum depended on the number of generations of growth on $\mathrm{NH}_{4}{ }^{+}$(Daesch \& Mortenson, 1972), a shorter lag ensuing where residual nitrogenase was present. Long pre-fixation lags recorded for $K$. pneumoniae may have arisen from depletion of amino acid pools (Yoch \& Pengra, I966; Parejko \& Wilson, 1970). Yeast extract, peptone, Casamino acids and various single amino acids shortened this lag (Yoch \& Pengra, 1966; Patil, Pengra \& Yoch, 1967). Parejko \& Wilson (1970) claimed that amino acids increased the nitrogenase content of a derepressed culture above that of one grown on $\mathrm{N}_{2}$ as sole nitrogen source. They also showed that 
K. pneumoniae synthesized nitrogenase in vacuo, so induction by substrate $\left(\mathrm{N}_{2}\right)$ does not appear to be involved in the regulation process.

We now report a study of the repression and derepression of nitrogenase activity by chemostat cultures of Klebsiella pneumoniae grown in defined nutrient conditions. This facultative anaerobe, which only fixes nitrogen at low or zero concentrations of dissolved oxygen, is more convenient than Azotobacter for repression-derepression studies with whole organisms: assays are performed anaerobically and the problem of defining an optimal $p \mathrm{O}_{2}$ for each assay (see Drozd \& Postgate, 1970; Drozd et al. 1972) is eliminated. We also provide evidence from the use of rifampicin and chloramphenicol for the locus of ammonium repression and the longevity of the mRNA specifying nitrogenase.

\section{METHODS}

Organism and culture. Klebsiella pneumoniae m5aI, a gift from Professor P. W. Wilson, was maintained at $20{ }^{\circ} \mathrm{C}$ in air on $2 \%$ nutrient agar slopes and subcultured monthly. Continuous cultures ( $200 \mathrm{ml}$; Baker, I968) were inoculated with Io to $20 \mathrm{ml}$ of an overnight culture grown on thioglycollate medium (Oxoid Ltd, London). The medium used for continuous cultures contained per litre: $20 \mathrm{~g}$ sucrose, I00 mg $\mathrm{MgCl}_{2} \cdot 6 \mathrm{H}_{2} \mathrm{O}, 36 \mathrm{mg}$ ferric citrate, $7.6 \mathrm{mg} \mathrm{Na} \mathrm{MoO}_{4} .2 \mathrm{H}_{2} \mathrm{O},{ }_{10} \cdot 4 \mathrm{~g} \mathrm{Na}_{2} \mathrm{HPO}_{4}$ and $3.4 \mathrm{~g} \mathrm{KH}_{2} \mathrm{PO}_{4}$. Except where mentioned, growth was limited by sulphate, present as $0.05 \mathrm{mM}-\mathrm{Na}_{2} \mathrm{SO}_{4}$. Ammonium succinate was included to repress nitrogenase synthesis without a drastic $\mathrm{pH}$ shift (Drozd et al. 1972) when required. Phosphate, $\mathrm{Na}_{2} \mathrm{SO}_{4}$ and ammonium succinate solutions were sterilized independently and subsequently added aseptically. Organisms were grown at $30 \pm 0.5{ }^{\circ} \mathrm{C}$ under an atmosphere of $\mathrm{N}_{2}$ flowing at about $200 \mathrm{ml} / \mathrm{min}$. Medium reservoirs were also maintained under an atmosphere of $\mathrm{N}_{2}$. The buffering capacity of the medium was sufficient to maintain the $\mathrm{pH}$ at $6 \cdot 7 \pm 0 \cdot \mathrm{I}$ under all conditions employed; automatic $\mathrm{pH}$ control was therefore omitted. The criteria of nutrient limitation were those of Hill, Drozd \& Postgate (1972). At dilution rates, $D$, of $0.20 \mathrm{~h}^{-1}$ or above on nitrogen-free medium, $\mathrm{N}_{2}$-limitation and sparse populations were inevitably obtained, so slower growth rates were used.

Batch (Io ml) cultures were grown in Pankhurst tubes (Campbell \& Evans, I969, modified by Postgate, 1972) at $30^{\circ} \mathrm{C}$. The medium used was as above except that $100 \mathrm{mg}$ $\mathrm{MgSO}_{4} \cdot 7 \mathrm{H}_{2} \mathrm{O} / 1$ replaced $\mathrm{MgCl}_{2} \cdot 6 \mathrm{H}_{2} \mathrm{O}, 20 \mathrm{~g}$ glucose $/ 1$ replaced sucrose and $\mathrm{Na}_{2} \mathrm{SO}_{4}$ was omitted.

Assay of nitrogenase activity. Acetylene reduction by whole organisms under anaerobic conditions was accepted as a measure of nitrogenase activity. The assumption was therefore made that, during derepression, the rate of acetylene reduction in vivo was limited by the amount of nitrogenase proteins present rather than by the availability of reductant or ATP. Conical flasks $(25 \mathrm{ml})$ were flushed with argon and capped with Suba-seal (Griffin \& George, Wembley, Middlesex) closures. Acetylene $(2 \mathrm{ml})$ was injected $\left(p \mathrm{C}_{2} \mathrm{H}_{2}=0.06 \mathrm{~atm}\right)$ and flasks were equilibrated at $30^{\circ} \mathrm{C}$ for $5 \mathrm{~min}$. The culture sample $(2 \mathrm{ml})$ was injected to start the assay, which was performed with gentle shaking at $30^{\circ} \mathrm{C}$. For time course studies, gas samples $(0.5 \mathrm{ml})$ were removed at intervals by syringe for gas chromatography and replaced by $0.5 \mathrm{ml}$ argon. Dilution of ethylene in this procedure was corrected for by measuring the concomitant dilution of acetylene. Where this correction was used the actual acetylene reduced was always $<\mathrm{I} \%$ of the total acetylene present. Generally, assays were stopped after $30 \mathrm{~min}$ with $0.2 \mathrm{ml}$ of $40 \%(\mathrm{w} / \mathrm{v}) \mathrm{NaOH}$. Gas samples $(0.5 \mathrm{ml})$ were injected into a Pye I04 gas-liquid chromatograph fitted with a $45 \mathrm{~cm}$ Porapak R column (I mm internal 
diam.) at $37^{\circ} \mathrm{C}$ with $\mathrm{N}_{2}$ as the carrier gas flowing at $7 \mathrm{ml} / \mathrm{min}$. Ethylene and acetylene peak heights were recorded and compared with standards.

Acetylene reduction by samples from sulphate-limited populations was linear for at least $5 \mathrm{~h}$ without further addition of sulphate; $\mathrm{N}_{2}$-limited populations similarly required no further addition. Carbon-limited populations were assayed in the presence of $10 \mathrm{mg}$ additional glucose $/ \mathrm{ml}$. In contrast to the partial inhibition observed in Azotobacter (Drozd et al. 1972), repressive concentrations of ammonium succinate had no significant effect on acetylene reduction rates assayed over $30 \mathrm{~min}$. Since acetylene reduction by whole organisms of Klebsiella can be inhibited by oxygen (Klucas, 1972), anaerobic handling of culture samples was maintained throughout. Activities thus measured agreed well with acetylene reduction rates measured in situ in the chemostat.

Analyses. Ammonia was estimated directly on supernatant fluid from centrifuged culture samples using the indophenol method of Chaney \& Marbach (1962). Standard amounts of ammonia in culture medium or in distilled water gave identical absorbances when assayed and nitrogen-free medium itself gave a very low blank. Microdiffusion was therefore unnecessary.

Dry weights were determined by washing organisms twice with distilled water and drying to constant weight at $80{ }^{\circ} \mathrm{C}$. Dried material was cooled and weighed in the presence of desiccant.

Bacterial densities were also recorded as $A_{540}$ measurements. $A_{540}$ for populations grown with $\mathrm{NH}_{4}{ }^{+}$or facing $\mathrm{N}_{2}$ was linearly related to dry wt organism/ml up to a value of 0.5 , corresponding to $0.58 \mathrm{mg}$ dry $\mathrm{wt} / \mathrm{ml}$.

Protein was estimated on washed organisms by the procedure of Lowry, Rosebrough, Farr \& Randall (I95I).

Derepression techniques. Derepression of nitrogenase synthesis in continuous cultures in situ was performed as described by Drozd et al. (1972). In some experiments described here a 'small-scale' method, developed for derepressing enzyme synthesis in several samples simultaneously under various conditions, was used. Samples $(2 \mathrm{ml})$ of fully repressed sulphate-limited continuous cultures were injected into $25 \mathrm{ml}$ conical flasks containing argon and acetylene as for an acetylene reduction assay (see above), except that flasks contained excess $(0.5 \mathrm{~mm}) \mathrm{Na}_{2} \mathrm{SO}_{4}$ plus any other required additions. Under these conditions excess $\mathrm{NH}_{4}{ }^{+}$was exhausted and derepression of nitrogenase synthesis proceeded. A time course of acetylene reduction was recorded for each sample. Since the rate of acetylene reduction gradually increased during derepression, a curve was obtained. Acetylene reduction rates (nitrogenase activities) were calculated by drawing tangents at suitable intervals.

\section{RESULTS}

Dependence of steady-state nitrogenase activity on the influent $\mathrm{NH}_{4}^{+}$concentration

An increase in the concentration of ammonium succinate in the medium supplied to a sulphate-limited, nitrogen-fixing continuous culture brought about a proportional decrease in the steady-state nitrogenase activity (Fig. I); steady states with partially repressed populations were thereby obtained. Free ammonium ion was only detected in the culture supernatant of fully repressed populations, although a narrow range of ammonium succinate concentrations gave complete repression without detectable free ammonium. When growth in the absence of fixed nitrogen was limited to $0.32 \mathrm{mg}$ dry wt bacteria/ml by $0.05 \mathrm{~mm}-\mathrm{Na}_{2} \mathrm{SO}_{4}$, $58 \mu \mathrm{g} \mathrm{N} / \mathrm{ml}$ was sufficient to effect complete repression of nitrogenase synthesis; for a popu- 


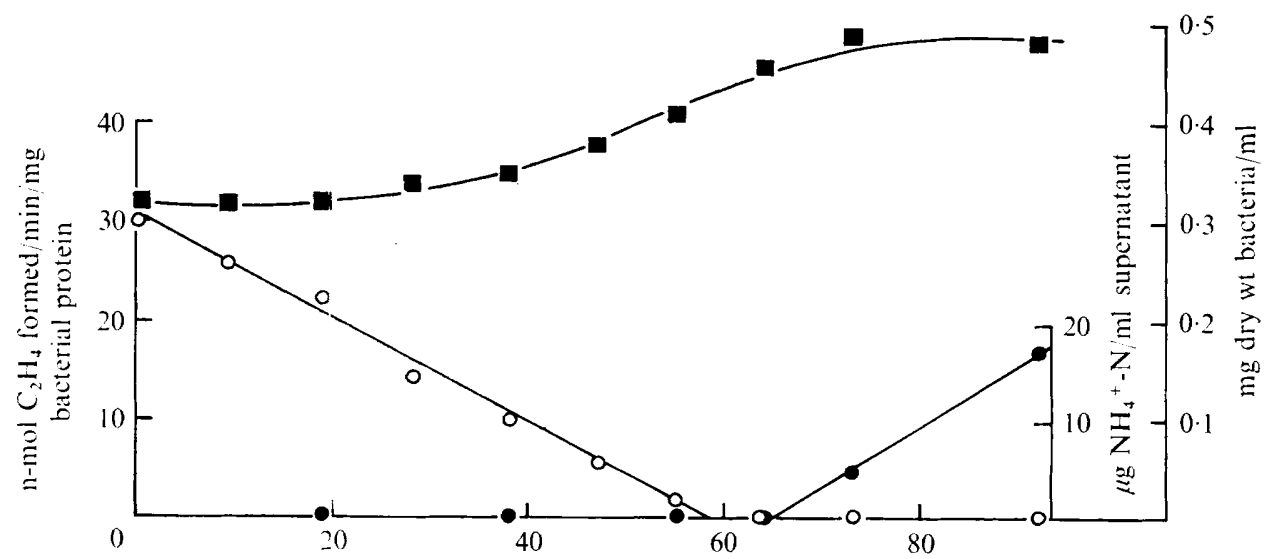

$\mu \mathrm{g} \mathrm{NH}{ }_{4}^{+}-\mathrm{N} / \mathrm{ml}$ of influent medium

Fig. I. Effect of increasing concentrations of ammonium succinate in the medium inflow of a $\mathrm{SO}_{4}{ }^{2--}$

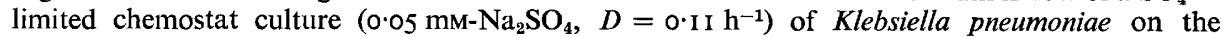
steady-state parameters. $\square$, Bacterial concentration; $O$, nitrogenase activity of culture; $\boldsymbol{O}$, concentration of $\mathrm{NH}_{4}{ }^{+}$in the culture supernatant.

lation at the same dilution rate limited to $0.18 \mathrm{mg}$ dry wt bacteria/ml by $0.025 \mathrm{~mm}-\mathrm{Na}_{2} \mathrm{SO}_{4}$, repression was just complete with $29 \mu \mathrm{g} \mathrm{N} / \mathrm{ml}$. The concentration of $\mathrm{NH}_{4}{ }^{+}$required for $100 \%$ repression therefore depended on the population density, nitrogenase activity being absent where the influent concentration of ammonium ion satisfied the total nitrogen requirement of the population. These findings are essentially similar to those of Drozd et al. (1972) for Azotobacter chroococcum.

Bacterial yields calculated from the biomass data in Fig. I, assuming effectively complete assimilation of sulphate, were $6.4 \times 10^{3} \mathrm{~g}$ bacteria/g-atom $\mathrm{S}$ for a fully derepressed population and $9.8 \times 10^{3}$ for a fully repressed one. This difference is larger than in Azotobacter chroococcum which, corrected for a misprint in Drozd et al. (1972), changed from $6.4 \times 10^{3}$ to $7 \cdot 7 \times 10^{3} \mathrm{~g} / \mathrm{g}$-atom S. Organisms from fully derepressed, partially repressed or fully repressed populations of Klebsiella pneumoniae all contained $75 \%$ dry wt as protein.

To check that the increased yield with ammonium succinate was not an effect due simply to the succinate added, $\mathrm{I} \cdot 5 \mathrm{mg}$ disodium succinate $/ \mathrm{ml}$ were added simultaneously to the culture vessel and medium reservoir of a fully derepressed continuous culture $\left(\mathrm{Na}_{2} \mathrm{SO}_{4}\right.$, $0.05 \mathrm{~mm} ; D, 0 . \mathrm{I} \mathrm{h} \mathrm{h}^{-1} ; 0.32 \mathrm{mg}$ dry wt bacteria $/ \mathrm{ml}$ ). No detectable increase in yield was observed after allowing the culture to regain steady state.

\section{Derepression of nitrogenase in sulphate-limited continuous culture}

The medium supply, containing $70 \mu \mathrm{g} \mathrm{N} / \mathrm{ml}$ as ammonium succinate, to a fully repressed population was replaced with one free of ammonium ions at zero time (Fig. 2). Nitrogenase activity was first detected about $65 \mathrm{~min}$ after the exhaustion of free ammonium ions from the culture. After a further $30 \mathrm{~min}$, enzyme activity increased linearly with time before giving a characteristic 'overshoot' and falling back to an activity which was subsequently maintained as the steady-state nitrogenase, activity of the derepressed population. The total time from exhaustion of $\mathrm{NH}_{4}{ }^{+}$to this steady-state activity was $340 \mathrm{~min}$, which is $90 \%$ of the doubling time ( $378 \mathrm{~min})$ at the dilution rate used. 


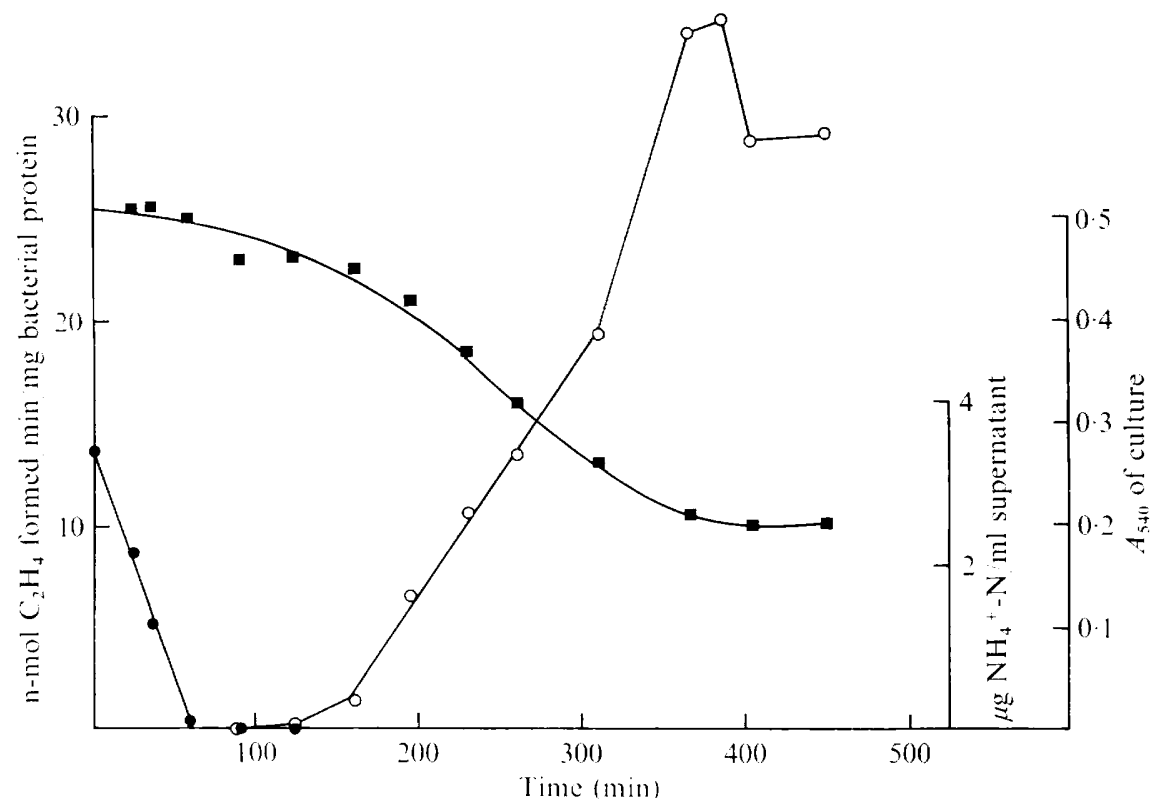

Fig. 2. Kinetics of derepression of nitrogenase activity in a chemostat culture of Klebsiella pneumoniae. The medium supply to a $\mathrm{SO}_{4}{ }^{2-}$-limited culture $\left(0.05 \mathrm{~mm}-\mathrm{Na}_{2} \mathrm{SO}_{4}\right)$ growing under $\mathrm{N}_{2}$ at $D=0 . \mathrm{I} \mathrm{I} \mathrm{h}^{-1}$ with $70 \mu \mathrm{g} \mathrm{N} / \mathrm{ml}$ as ammonium succinate, was abruptly changed to one free of $\mathrm{NH}_{4}{ }^{+}$. $\bigcirc$, Acetylene reduction activity; $\bullet$, free ammonium ions in the culture; $\square, A_{540}$ of culture.

\section{The effect of Casamino acids on the derepression of nitrogenase}

In experiments otherwise similar to that shown in Fig. 2, 10 $\mu \mathrm{g} \mathrm{N} / \mathrm{ml}$ as vitamin-free Casamino acids, whether present all the time or added to the culture vessel 20 min before exhaustion of $\mathrm{NH}_{4}^{+}$, did not decrease the delay before detecting activity nor increase the rate of nitrogenase synthesis.

To test a wider variety of conditions the 'small-scale' procedure was used (see Methods). Derepression of nitrogenase in the absence of amino-acid $\mathrm{N}$ by this procedure ceased at a specific activity of about Io n-mol $\mathrm{C}_{2} \mathrm{H}_{4}$ formed $/ \mathrm{min} / \mathrm{mg}$ bacterial protein. This was low, in agreement with Parejko \& Wilson's (I970) report of only limited synthesis of nitrogenase under an inert gas phase. Fig. 3 shows the effect on derepression of various amounts of Casamino acids added after $\mathrm{NH}_{4}{ }^{+}$had been exhausted. At low concentrations Casamino acids did not affect the lag, the rate of enzyme synthesis or the final activity; higher concentrations ( $\mathrm{I} 6 \mu \mathrm{g} \mathrm{N} / \mathrm{ml}$ and above) were repressive. Comparable derepression experiments with different initial excesses of $\mathrm{NH}_{4}{ }^{+}$are shown in Table $\mathrm{I}$. Where high levels of ammonium had to be exhausted before derepression could start, the subsequent lag before linear synthesis of nitrogenase activity was longer. Although Casamino acids had no effect on the shorter lags, when derepression was imminent they shortened a longer lag appreciably. In conditions similar to those of experiment 5, Table I, Casamino acids also increased the rate of enzyme synthesis after derepression. The final activity was increased by $50 \%$ to $15 \mathrm{n}-\mathrm{mol} \mathrm{C}_{2} \mathrm{H}_{4}$ formed $/ \mathrm{min} / \mathrm{mg}$ bacterial protein. Yeast extract ( $10 \mu \mathrm{g} \mathrm{N} / \mathrm{ml}$ ) and aspartate (1o $\mu \mathrm{g} \mathrm{N} / \mathrm{ml}$ ) were in this instance as effective as Casamino acids in shortening the lag but had little effect on the rate of nitrogenase synthesis or final activity.

In derepression experiments in the chemostat (e.g. Fig. 2) during which sulphate-limitation was maintained throughout, the time taken before acetylene reduction activity increased 


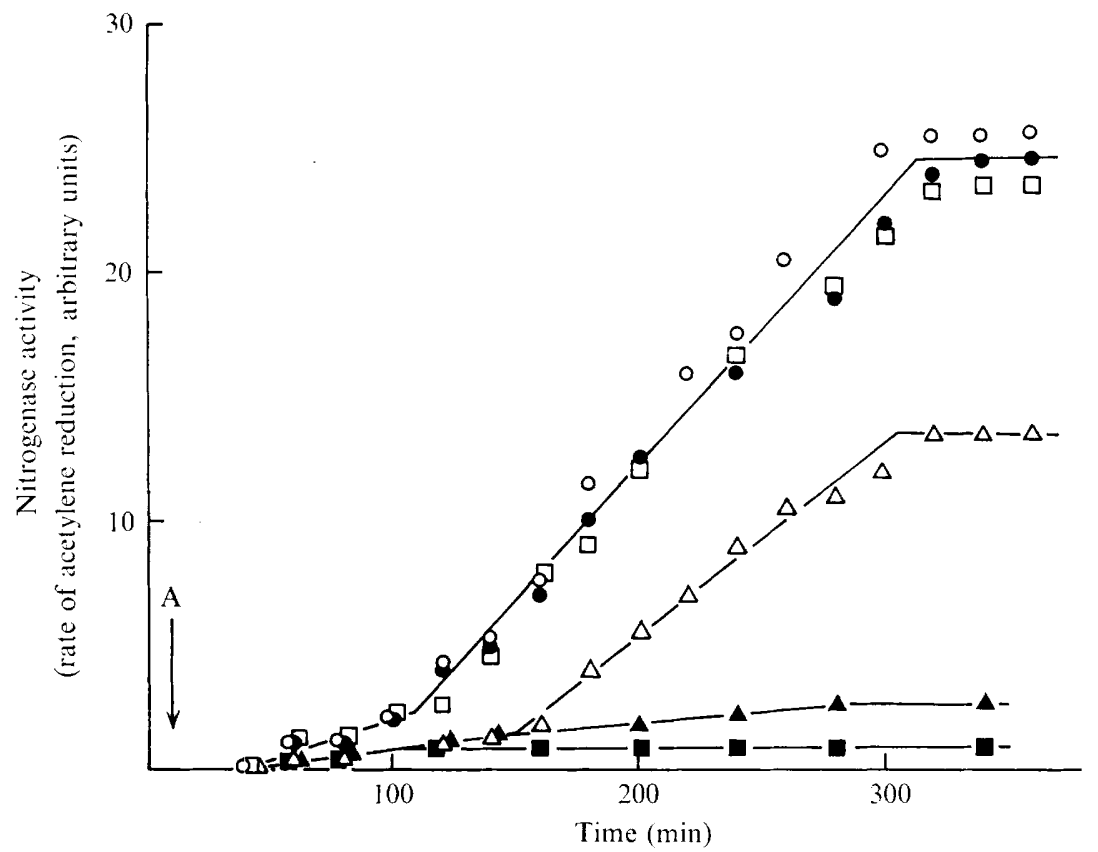

Fig. 3. Effect of various amounts of Casamino acids on derepression of nitrogenase. At zero time,

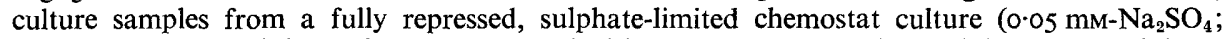
$D=0 . I_{I ~ ~^{-1}}$ ) were injected into flasks gassed with $\mathrm{C}_{2} \mathrm{H}_{2}$ in argon, and containing excess sulphate. At $\mathrm{A}$, free ammonium ion was $<\mathrm{I} \mu \mathrm{g} \mathrm{N} / \mathrm{ml}$, and Casamino acids were added to $0.8(\mathbf{0}), 8(0)$, $\mathrm{I} 6(\triangle), 80(\Delta)$, and $\mathrm{r} 60(\boldsymbol{\square}) \mu \mathrm{g} \mathrm{N} / \mathrm{ml}$. $\square$, Control with no addition.

Table I. Influence of the time required to exhaust excess ammonium ion on the subsequent lag in derepressing nitrogenase by the 'small-scale' method (see Methods)

\begin{tabular}{|c|c|c|c|c|}
\hline \multirow[b]{2}{*}{ Experiment } & \multirow[b]{2}{*}{$\begin{array}{l}\text { Excess } \mathrm{NH}_{4}^{+} \\
(\mu \mathrm{g} \mathrm{N} / \mathrm{ml})\end{array}$} & \multirow[b]{2}{*}{$\begin{array}{l}\text { Time at which } \\
\mathrm{NH}_{4}^{+} \text {exhausted } \\
\text { (min) }\end{array}$} & \multicolumn{2}{|c|}{$\begin{array}{c}\mathrm{Lag} * \text { before derepression of } \\
\text { nitrogenase (min) }\end{array}$} \\
\hline & & & No addition & $\begin{array}{c}\text { Casamino acids } \\
\text { added }(10 \mu \mathrm{g} \mathrm{N} / \mathrm{ml})\end{array}$ \\
\hline I & n.d. & 一 & 86 & 84 \\
\hline 2 & 0.5 & - & 106 & 103 \\
\hline 3 & $3 \cdot 2$ & 40 & 82 & 一 \\
\hline 4 & $8 \cdot 0$ & 100 & 110 & 一 \\
\hline 5 & 23.0 & I 54 & 138 & 90 \\
\hline 6 & $40 \cdot 0$ & 190 & 175 & - \\
\hline
\end{tabular}

n.d., Not detected; - , not determined.

* 'Lag' was the time between exhaustion of $\mathrm{NH}_{4}{ }^{+}$and the point to which linear derepression of nitrogenase activity could be extrapolated.

linearly with time was independent of the amount of excess $\mathrm{NH}_{4}{ }^{+}$to be exhausted. The longer lags recorded in Table I only arose where sulphate-limitation had been relieved for at least $2 \mathrm{~h}$. Under those conditions it seems most likely that nitrogen became growthlimiting. The major component of these lags was the time taken for the rate of nitrogenase synthesis to become linear; the delay before first appearance of acetylene reduction, obtained by extrapolation of the non-linear part of the curve to zero, was almost invariant at $40 \pm 5 \mathrm{~min}$. The length of the lag and its relief by Casamino acids therefore depended on nutritional status. 
Table 2. Effect of various nitrogen supplements on acetylene reduction by batch cultures of Klebsiella pneumoniae

\begin{abstract}
$\mathrm{NH}_{4}$-grown inocula were cultured anaerobically in Pankhurst tubes (see Methods). Nitrogen supplements to the nitrogen-free medium were as shown. Acetylene $\left(p \mathrm{C}_{2} \mathrm{H}_{2}=0.03\right)$ was added to the $\mathrm{N}_{2}$ gas phase $5 \mathrm{~h}$ after inoculation.
\end{abstract}

\begin{tabular}{|c|c|c|c|}
\hline \multirow[b]{2}{*}{ Supplement } & \multirow[b]{2}{*}{$\mu \mathrm{g} \mathrm{N} / \mathrm{ml}$} & \multicolumn{2}{|c|}{ Twenty-four hours after inoculation } \\
\hline & & Growth* & $\begin{array}{c}\mathrm{n}-\mathrm{mol} \mathrm{C}_{2} \mathrm{H}_{4} / \mathrm{ml} \\
\text { gas phase }\end{array}$ \\
\hline Diammonium succinate & 140 & $+t+t$ & o \\
\hline $\mathrm{KNO}_{3}$ & 140 & $++t+$ & 0 \\
\hline L-Aspartate & 160 & $+t+t$ & 290 \\
\hline Vitamin-free & & & \\
\hline Casamino acids & 100 & $+t+t$ & 213 \\
\hline Yeast extract & 100 & $++t+$ & 330 \\
\hline None & o & + & 87 \\
\hline
\end{tabular}

\title{
Repression by aspartate
}

Certain amino acids (e.g. L-aspartate) eliminated the diauxic growth lag following the exhaustion of a limiting concentration of $\mathrm{NH}_{4}{ }^{+}$from batch cultures of Klebsiella pneumoniae (Yoch \& Pengra, 1966; Patil et al. 1967). Aspartate appeared to stimulate adaptive formation of the nitrogenase system; assimilation of aspartate and $\mathrm{N}_{2}$ occurred simultaneously. In batch cultures, we have confirmed these observations. L-Aspartate ( $160 \mu \mathrm{g} \mathrm{N} / \mathrm{ml})$, Casamino acids ( $100 \mu \mathrm{g} \mathrm{N} / \mathrm{ml}$ ) or yeast extract (I00 $\mu \mathrm{g} \mathrm{N} / \mathrm{ml}$ ) allowed good growth without substantial repression of nitrogenase activity (Table 2). Parallel cultures provided with $\mathrm{NH}_{4}{ }^{+}$or $\mathrm{NO}_{3}{ }^{-}$ grew well but showed no acetylene reduction activity. Batch cultures of nitrogen-fixing anaerobes in nitrogen-deficient media are $\mathrm{N}_{2}$-limited, in that $\mu_{\max }$ is determined by the rate of nitrogen fixation (Hill et al. 1972). A chemostat culture at $D=0 \cdot \mathrm{II} \mathrm{h}^{-1}$ was made $\mathrm{N}_{2}$ limited by increasing the influent $\mathrm{Na}_{2} \mathrm{SO}_{4}$ to $0.30 \mathrm{~mm}$ giving, in the absence of fixed nitrogen, a population at steady state of $0.69 \mathrm{mg}$ dry wt $/ \mathrm{ml}$, which reduced $28 \mathrm{n}-\mathrm{mol}$ acetylene $/ \mathrm{min} / \mathrm{mg}$ bacterial protein. The addition of $95 \mu \mathrm{g} \mathrm{N} / \mathrm{ml}$ as L-aspartate to such a population increased the biomass to $0.98 \mathrm{mg} \mathrm{dry} \mathrm{wt} / \mathrm{ml}$ whereas the nitrogenase specific activity was virtually unchanged at $24 \mathrm{n}-\mathrm{mol}$ acetylene $/ \mathrm{min} / \mathrm{mg}$ bacterial protein. Therefore, although aspartate- $\mathrm{N}$ increased the yield of organisms obtained it did not repress nitrogenase. By elimination of other possibilities, this culture was shown to be $\mathrm{N}$-limited.

However, L-aspartate $(95 \mu \mathrm{g} \mathrm{N} / \mathrm{ml}$ ) added to the medium reservoir of a sulphate-limited, nitrogen-fixing continuous culture $\left(\mathrm{Na}_{2} \mathrm{SO}_{4}, 0.05 \mathrm{mM} ; D, 0 . \mathrm{I} \mathrm{h} \mathrm{h}^{-1}\right)$ completely repressed nitrogenase: no activity was present after allowing the culture to regain steady state, and the biomass increased to $0.48 \mathrm{mg}$ dry wt/ml (which is characteristic of a similar population completely repressed by ammonium; see Fig. I). This concentration of L-aspartate was equivalent in terms of $\mathrm{N} / \mathrm{ml}$ to a fully repressive concentration of ammonium.

When $142 \mu \mathrm{g} \mathrm{N} / \mathrm{ml}$ as L-aspartate were added to the medium supply to a glucose-limited, nitrogen-fixing continuous culture $\left(5 \mathrm{~g}\right.$ glucose $\left./ 1 ; D, 0^{\cdot} \mathrm{IO}^{-1}\right)$, the steady-state nitrogenase activity was undetectably low, and $\mathrm{I} 4 \mu \mathrm{g} \mathrm{N} / \mathrm{ml}$ ammonium ion were present in the culture supernatant. Clearly the ability to effect repression from exogenous aspartate was determined by the nutritional status of the population (see Discussion). 


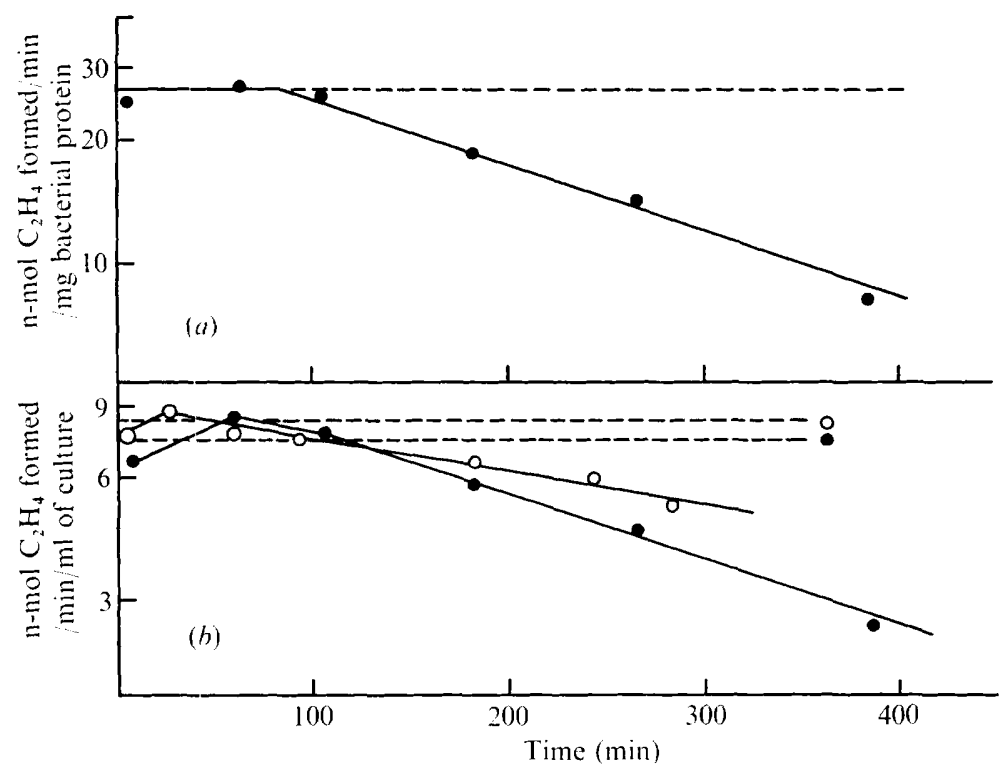

Fig. 4. Kinetics of repression of nitrogenase activity of Klebsiella pneumoniae in sulphate-limited con-

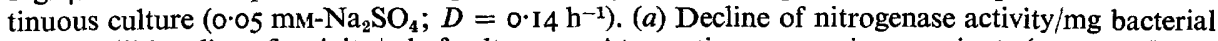
protein. (b) Decline of activity $/ \mathrm{ml}$ of culture. A, At zero time ammonium succinate ( $120 \mu \mathrm{g} / \mathrm{ml}$ ) was added to the culture vessel and the medium inflow changed to one introducing a similar $\mathrm{NH}_{4}{ }^{+}$ concentration. The same data are plotted in $(a)$ and $(b)$; a difference arises from the small increase in bacterial protein $/ \mathrm{ml}$ during the experiment. $O$, A second experiment in which $100 \mu \mathrm{g} / \mathrm{ml}$ chloramphenicol were added with repressive ammonium. Dashed lines represent nitrogenase activities of cultures before additions were made.

\section{Kinetics of ammonium repression of nitrogenase synthesis in sulphate-limited continuous culture}

Ammonium succinate ( $20 \mu \mathrm{g} \mathrm{N} / \mathrm{ml}$ ) was added to the culture vessel of an $\mathrm{N}_{2}$-fixing chemostat culture limited by $\mathrm{Na}_{2} \mathrm{SO}_{4}$ and the medium input at once changed to one introducing a medium containing $120 \mu \mathrm{g} \mathrm{NH}_{4}{ }^{+} \mathrm{N} / \mathrm{mI}$. For about $75 \mathrm{~min}$ no decrease in nitrogenase activity was observed, indicating continued production of active enzyme (Fig. $4 a$ ). Subsequently nitrogenase activity declined logarithmically faster than 'wash-out' with a half-life of $\mathrm{I} 90 \mathrm{~min}$ compared with a doubling time for the population $\left(D=0.14 \mathrm{~h}^{-1}\right)$ of $288 \mathrm{~min}$. When chloramphenicol $(100 \mu \mathrm{g} / \mathrm{ml})$ was added simultaneously with repressive $\mathrm{NH}_{4}{ }^{+}$and the dilution of the culture continued as normal, a delay of about $30 \mathrm{~min}$ (Fig. 4 b) was still observed, suggesting that active enzyme was produced without protein synthesis de novo. Here we have assumed that chloramphenicol produced its usual response - a rapid and substantial inhibition of protein synthesis. This appeared to be so since both bacterial density ( $A_{540}$ of culture) and bacterial protein $/ \mathrm{ml} \mathrm{declined} \mathrm{immediately} \mathrm{following} \mathrm{the} \mathrm{addi-}$ tion of the inhibitor (not shown in the Figure). In this experiment the total nitrogenase activity subsequently declined by wash-out at a similar logarithmic rate to the total protein content of the culture (see Table 3 ). In the absence of further protein synthesis, therefore, nitrogenase turnover was small.

\section{Separation of transcription and translation during derepression of nitrogenase}

In principle, if rifampicin (an inhibitor of initiation of RNA synthesis : see Sippel \& Hartman, I968) and chloramphenicol (an inhibitor of mRNA translation) are added to parallel 
Table 3. Half-lives of parameters during ammonium repression of nitrogenase activity in continuous culture

\begin{tabular}{|c|c|}
\hline Parameter & $t_{0.5}(\mathrm{~min})$ \\
\hline $\begin{array}{l}\text { Nitrogenase activity } \\
\text { (n-mol } \mathrm{C}_{2} \mathrm{H}_{4} \text { formed } / \mathrm{min} / \mathrm{mg} \\
\text { bacterial protein) after } \\
\text { addition of } \mathrm{NH}_{4}^{+} \text {, see Fig. } 4(a)\end{array}$ & 190 \\
\hline $\begin{array}{l}\text { Nitrogenase activity } \\
\text { (n-mol } \mathrm{C}_{2} \mathrm{H}_{4} \text { formed } / \mathrm{min} / \mathrm{ml} \\
\text { culture) after addition } \\
\text { of } \mathrm{NH}_{4}^{+} \text {, see Fig. } 4(b)\end{array}$ & 195 \\
\hline $\begin{array}{l}\text { Nitrogenase activity } \\
\text { (n-mol } \mathrm{C}_{2} \mathrm{H}_{4} \text { formed } / \mathrm{min} / \mathrm{ml} \\
\text { culture) after addition of } \\
\mathrm{NH}_{4}^{+} \text {and chloramphenicol, } \\
\text { see Fig. } 4(b)\end{array}$ & 240 \\
\hline $\begin{array}{l}\text { Bacterial protein in culture } \\
\text { after addition of } \mathrm{NH}_{4}^{+} \text {and } \\
\text { chloramphenicol }\end{array}$ & 264 \\
\hline $\begin{array}{l}\text { Theoretical } t_{0.5} \text { of 'wash-out' } \\
\text { in continuous culture at } \\
D=0.14 \mathrm{~h}^{-1}\end{array}$ & 288 \\
\hline
\end{tabular}

cultures just beginning to derepress, chloramphenicol should curtail derepression more abruptly than rifampicin. A higher final activity should arise with rifampicin as a consequence of translation of pre-formed mRNA. Comparison of the effect of these inhibitors with that of $\mathrm{NH}_{4}{ }^{+}$during derepression of nitrogenase should indicate the level at which $\mathrm{NH}_{4}{ }^{+}$acts. The experiments described here are based on studies by Kepes (1969) and Jacquet \& Kepes (1969) on the expression of the lactose operon of Escherichia coli.

Samples were removed at intervals following the exhaustion of $\mathrm{NH}_{4}{ }^{+}$from the culture in a derepression experiment carried out as for Fig. 2. Portions $(4 \times 2 \mathrm{ml})$ were treated as in the 'small-scale' derepression method; flasks finally contained: (i) $200 \mu \mathrm{g}$ rifampicin $/ \mathrm{ml}$,

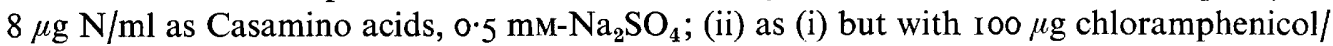
$\mathrm{ml}$ instead of rifampicin; (iii) as (i) but with $200 \mu \mathrm{g} \mathrm{N} / \mathrm{ml}$ as ammonium succinate instead of rifampicin; (iv) no additions. Flask (iv) was therefore a normal acetylene reduction assay and contained no additional sulphate. Linear rates of acetylene reduction were recorded; these were obtained immediately with treatments (ii) and (iv) but only after about 40 min with treatments (i) and (iii), during which time the nitrogenase activity increased, presumably due to continued enzyme synthesis. Acetylene reduction rates finally obtained for treatments (i) to (iv) at intervals during derepression are plotted in Fig. 5, which permits three conclusions: since rifampicin added shortly after the exhaustion of $\mathrm{NH}_{4}+$ did not block eventual appearance of some nitrogenase activity, nitrogenase mRNA must already have been initiated at this time; initiation of nitrogenase mRNA preceded appearance of enzyme activity by about $20 \mathrm{~min}$; and since $\mathrm{NH}_{4}{ }^{+}$paralleled the effect of rifampicin, in that it allowed further enzyme synthesis for a short period, repression by $\mathrm{NH}_{4}{ }^{+}$was apparently at the level of mRNA synthesis.

Complementary results were obtained from a further experiment in which either chloramphenicol, rifampicin, or ammonium succinate were added to organisms which were just beginning to derepress. Here, the 'small-scale' derepression method was employed (see Methods). Chloramphenicol, rifampicin and ammonium succinate all curtailed derepression. Chloramphenicol was almost immediate in its effect whereas more enzyme was synthesized 


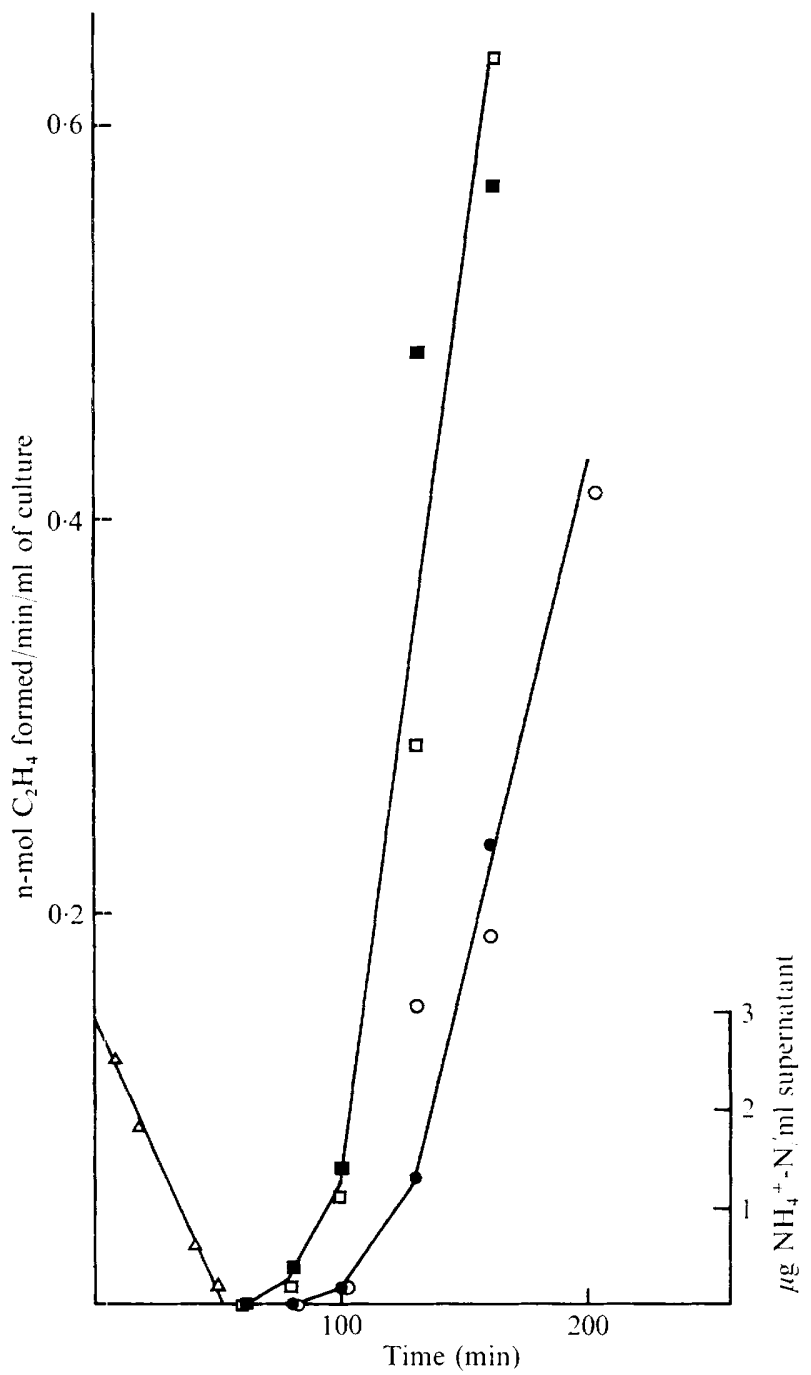

Fig. 5. Separation of transcription and translation during derepression of nitrogenase. The medium supply, containing $70 \mu \mathrm{g} \mathrm{N} / \mathrm{ml}$ as ammonium succinate, to a sulphate-limited chemostat culture $\left(0.05 \mathrm{mM}_{-} \mathrm{Na}_{2} \mathrm{SO}_{4} ; D=0 . \mathrm{I} \mathrm{h} \mathrm{h}^{-1}\right)$, was changed to one free of ammonium ions at zero time. $\triangle$, Free ammonium ions in culture. At intervals following exhaustion of $\mathrm{NH}_{4}{ }^{+}$, culture samples were removed and were either untreated $(\bullet)$, or treated with Casamino acids $(8 \mu \mathrm{g} \mathrm{N} / \mathrm{ml})$ and $\mathrm{Na}_{2} \mathrm{SO}_{4}(0.5 \mathrm{~mm})$ in addition to: $\square$, rifampicin $(200 \mu \mathrm{g} / \mathrm{ml}) ; \square$, ammonium succinate $(200 \mu \mathrm{g} \mathrm{N} / \mathrm{ml})$; or $O$, chloramphenicol (Ioo $\mu \mathrm{g} / \mathrm{ml}$ ). Final acetylene reduction rates obtained after allowing any further enzyme synthesis to occur are plotted against the time of sampling.

in the presence of rifampicin or ammonium over about $40 \mathrm{~min}$ (Fig. 6). The accelerated derepression and higher final activity with ammonium suggested that translation of residual message was stimulated. This was further substantiated by showing that ammonium succinate and rifampicin added together gave the same effect as ammonium succinate alone, whereas ammonium succinate and chloramphenicol together paralleled the result of chloramphenicol alone. In the experiment shown in Fig. 6, the inhibitors were added during the lag, i.e. the period before translation of message reached steady state (see Kepes, 1969; 


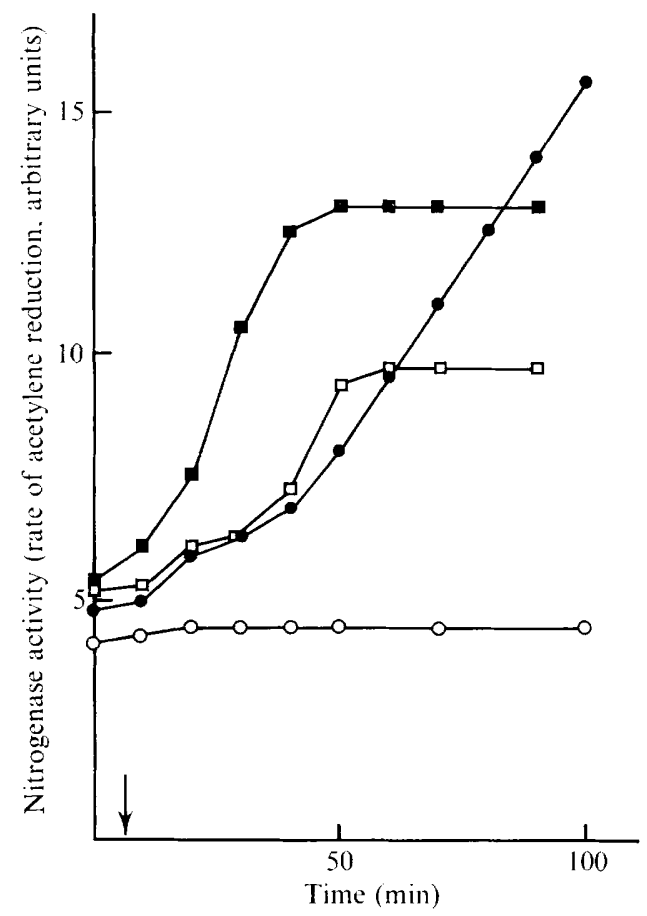

Fig. 6

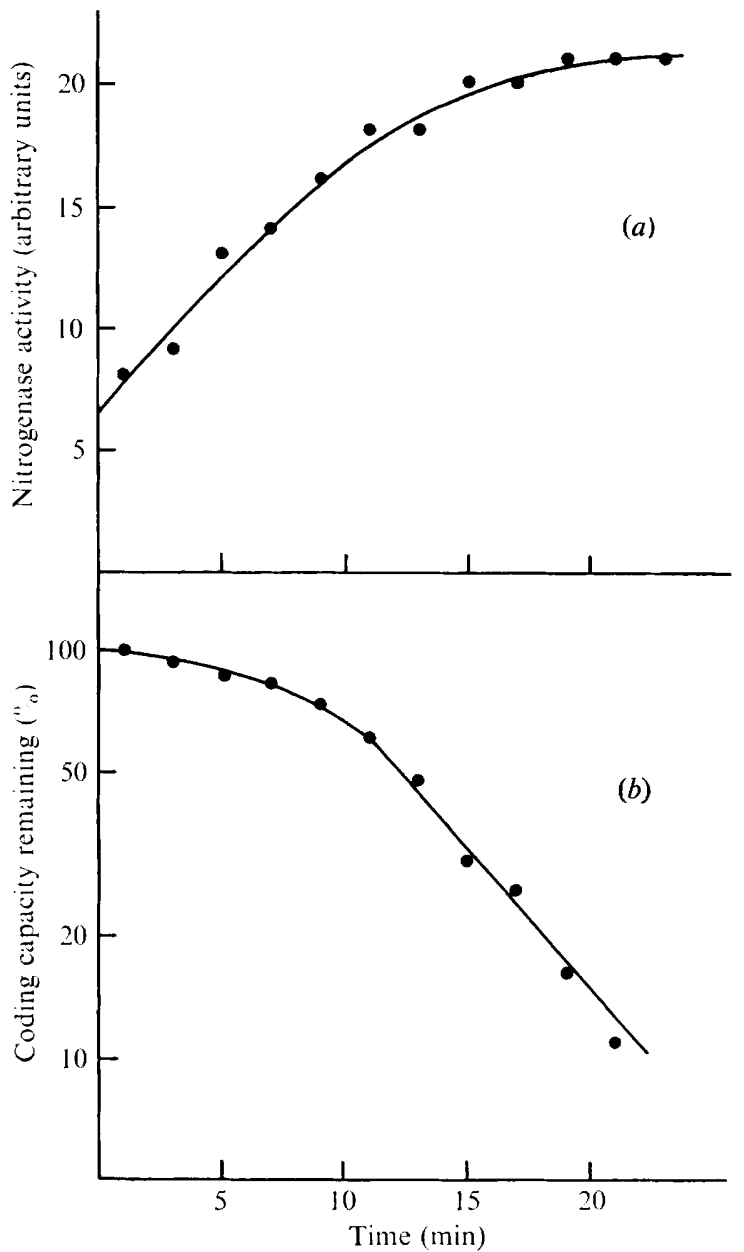

Fig. 7

Fig. 6. Effects of inhibitors on derepression using the 'small-scale' procedure (see Methods). Parallel samples from a fully repressed, sulphate-limited continuous culture (0.05 mM- $\mathrm{Na}_{2} \mathrm{SO}_{4}$; $D=0 . \mathrm{I} \mathrm{h} \mathrm{h}^{-1}$ ) had exhausted excess $\mathrm{NH}_{4}{ }^{+}$in the presence of additional $(0.5 \mathrm{~mm}) \mathrm{Na}_{2} \mathrm{SO}_{4}$ and were in an early stage of derepression at time zero. Ammonium succinate $(200 \mu \mathrm{g} \mathrm{N} / \mathrm{ml})$, $\mathbf{\square}$; rifampicin $(200 \mu \mathrm{g} / \mathrm{ml}), \square$; or chloramphenicol, $\bigcirc$; were added at $5 \mathrm{~min}$ (arrowed), and further derepression of nitrogenase activity followed in each case. Control to which no addition was made.

Fig. 7. Decay of 'coding capacity' for nitrogenase synthesis following inhibition of mRNA initiation by rifampicin. (a) A sample from a fully repressed, sulphate-limited continuous culture

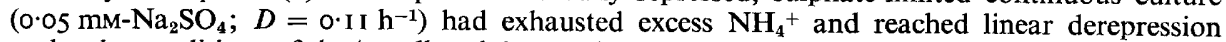
under the conditions of the 'small-scale' procedure. $200 \mu \mathrm{g}$ rifampicin/ml were added at time zero and further derepression recorded. (b) Logarithmic decay of message specifying nitrogenase. Each point represents the increment in nitrogenase activity for each successive two-minute interval in $(a)$.

Coffman, Norris \& Koch, 1971). Consequently, apparent coding capacity continued to increase even in the presence of rifampicin. When rifampicin was added during the linear phase of derepression, enzyme activity increased to a maximum over $20 \mathrm{~min}$ (Fig. $7 \mathrm{a}$ ). The semi-log plot of successive increments of activity (Fig. $7 b$ ) gave a half-life for the coding 
capacity of pre-formed message of $4.4 \pm 0.2 \mathrm{~min}$. A similar half-life of $4.7 \pm 0.2 \mathrm{~min}$ was obtained in a comparable experiment in which ammonium succinate and rifampicin were added together.

\section{DISCUSSION}

Yield coefficients in sulphate-limited continuous cultures of Klebsiella pneumoniae. The $50 \%$ increase in yield for an ammonium-assimilating population over a nitrogen-fixing one is unlikely to be explained merely by the known high sulphur content of nitrogenase. It may be related to the fact that carbon-limited populations show a lowered efficiency of conversion of energy source into biomass when $\mathrm{N}_{2}$ replaces $\mathrm{NH}_{4}{ }^{+}$as the nitrogen source - a phenomenon more pronounced in Klebsiella pneumoniae than in Azotobacter chroococcum (see Hill et al. 1972).

Derepression of nitrogenase synthesis. Under conditions of sulphate limitation, derepression of nitrogenase proceeded with a shorter lag following exhaustion of ammonium ion than has previously been reported (Lindsay, 1963; Mahl \& Wilson, 1968). Even so, a comparable lag was absent in similar experiments with Azotobacter chroococcum (Drozd et al. 1972). With Klebsiella pneumoniae the shortened lag in expression of nitrogen fixation under sulphate-limited conditions was not further decreased by exogenous Casamino acids. A longer lag, however, was observed when ammonium was exhausted under conditions where presumably nitrogen became growth limiting; conditions which, for example, lead to a high degree of catabolite repression (see Mandelstam, I962). Such a lag was decreased by Casamino acids; this is consistent with the observation of Yoch \& Pengra (1966) that the amino acid pool of $K$. pneumoniae is depleted during derepression of nitrogenase. Synthesis of nitrogenase can therefore be influenced by the nutritional status of the bacterial population.

During derepression under an argon-acetylene gas phase, ammonium stimulated enzyme synthesis before the repressive effect was observed (Fig. 6). The derepression rate doubled transiently, yet we know that ammonium did not stabilize existing message since its half-life was unaltered in the presence of ammonium succinate. Hence ammonium stimulated translation to such an extent that twice as much enzyme was obtained from the amount of mRNA formed or initiated before repressor was added. A similar effect of $\mathrm{NH}_{4}{ }^{+}$in vivo was observed by Rigano \& Violante (1973) during derepression of nitrate reductase synthesis by Cyanidium caldarium. Ammonium ions stimulate cell-free amino acid incorporation (Lubin \& Ennis, 1964); high $\mathrm{NH}_{4}{ }^{+}$concentrations are required for ribosomal stability in vitro (Hartman, Nolan \& Amaya, I97I) and for the peptidyl transferase reaction (Miskin, Zamir \& Elson, 1970). Under argon, only a limited amount of nitrogenase was derepressed, as previously observed by Parejko \& Wilson, I970; Casamino acids added prior to derepression increased the final activity obtained in one instance. Klebsiella pneumoniae, therefore, did not synthesize nitrogenase completely when only endogenous nitrogen sources were available.

Repression of nitrogenase synthesis. During the initial stages of repression by $\mathrm{NH}_{4}{ }^{+}$ (Fig. 4) we have inferred continual production of active enzyme in the absence of protein synthesis de novo. Whether activation of inactive nitrogenase proteins is continually taking place in fully derepressed populations remains to be tested critically. During purification of nitrogenase from Clostridium pasteurianum an inactive derivative of the iron-molybdenum protein which lacks molybdenum and much of its normal complement of iron has been separated (Zumft, Cretney, Huang, Mortenson \& Palmer, 1972). If such a species occurs in vivo, reactivation in the absence of further protein synthesis may be possible. To be 
involved in derepression, such an activation process must be rapid, since derepression was curtailed immediately by chloramphenicol (see Fig. 5).

Nitrogenase activity was primarily diluted out during repression. The small amount of nitrogenase turnover depended on continued protein synthesis (Table 3). In agreement with Shah et al. (1972), there appears to be no specific mechanism for rapidly degrading or inactivating nitrogenase following repression of its synthesis by ammonium.

Under certain conditions, other nitrogen sources may be partially or wholly as effective as $\mathrm{NH}_{4}{ }^{+}$in repressing nitrogenase synthesis. These include glutamine in Klebsiella pneumoniae (Parejko \& Wilson, 1970), aspargine (Wilson, Hull \& Burris, 1943; St John \& Brill, I972), urea (Wilson et al. I943; Hardy \& Knight, I967) and nitrate (Wilson et al. 1943; Drozd et al. 1972) in Azotobacter. This diversity suggests that a common intermediate, the most obvious being $\mathrm{NH}_{4}{ }^{+}$, is the effector of repression. Here, L-aspartate repressed nitrogenase under sulphur- or carbon-limited conditions of growth but not under nitrogen limitation. We therefore suggest that, under sulphur and carbon limitation, L-aspartate is deaminated at a sufficient rate to maintain fully repressive concentrations of $\mathrm{NH}_{4}{ }^{+}$, whereas under nitrogen limitation $\mathrm{NH}_{4}{ }^{+}$produced from aspartate does not accumulate.

When the nitrogen fixation genes were transferred from Klebsiella pneumoniae to Escherichia coli (Dixon \& Postgate, 1972) repression of nitrogenase synthesis by ammonium was conserved, indicating that regulatory and structural genes are closely linked. This concept of a nif operon has more recently been expanded by Streicher, Gurney \& Valentine (1972). Here we have provided direct evidence that ammonium repression is effective at the level of mRNA synthesis. During derepression of nitrogenase in Klebsiella pneumoniae, however, considerable lags were observed even after acetylene reduction became just detectable (see Fig. 2, 3, 5 and 6). Such lags have been associated with the time taken for messenger RNA translation to come to steady state (see Kepes, I969). Here the length of the lag depended on nutritional status, demonstrating that even though the repressive effect of $\mathrm{NH}_{4}{ }^{+}$on the nif genes was relieved, efficient and rapid synthesis of nitrogenase did not necessarily follow.

The coding capacity of pre-formed message for nitrogenase synthesis decayed with a halflife of about $4.5 \mathrm{~min}$ with or without $\mathrm{NH}_{4}{ }^{+}$. Decay rates of different mRNAs in Escherichia coli have been summarized by Blundell, Craig \& Kennel (1972) and are generally more rapid than the figure reported here. These authors, however, quote decay rates which vary considerably with different strains or with growth conditions. Here we have measured a decay rate during derepression at $30^{\circ} \mathrm{C}$ under non-growing conditions. Nitrogenase of Klebsiella pneumoniae comprises two component proteins resembling those from other organisms (Eady, Smith, Cook \& Postgate, 1972). Since the larger iron-molybdenum component consists of two non-identical classes of subunit, there are at least three structural genes involved in nitrogenase synthesis. Shah et al. (1972) have demonstrated that the component proteins are synthesized co-ordinately in Azotobacter vinelandii. Presumably the decay rate of coding capacity for nitrogenase sy rithesis measured here represents the decay rate of the fastest clecaying cistron.

We are grateful to Lepetit Pharmaceuticals Ltd for the gift of rifampicin, and to Dr R. A. Dixon of this research unit for useful discussion throughout the course of this work. 


\section{REFERENCES}

BAKER, K. (1968). Low cost continuous culture apparatus. Laboratory Practice 17, 817-824.

Blundell, M., Craig, E. \& KenNell, D. (1972). Decay rates of different mRNA in E. coli and models of decay. Nature New Biology 238, 46-49.

Campbell, N. E. R. \& Evans, H.'J. (1969). Use of Pankhurst tubes to assay acetylene reduction by facultative and anaerobic nitrogen-fixing bacteria. Canadian Journal of Microbiology 15, 1342-I 343 .

Chaney, A. L. \& Marbach, E. P. (1962). Modified reagents for determination of urea and ammonia. Clinical Chemistry 8, 130-132.

COFfMAN, R. L., Norris, T. E. \& КосH, A. L. (I971). Chain elongation rate of messenger and polypeptides in slowly growing Escherichia coli. Journal of Molecular Biology 60, I-19.

Daesch, G. \& Mortenson, L. E. (1972). Effect of ammonia on the synthesis and function of the $\mathrm{N}_{2}$-fixing enzyme system in Clostridium pasteurianum. Journal of Bacteriology 110, 103-109.

Dixon, R. A. \& Postgate, J. R. (1972). Genetic transfer of nitrogen fixation from Klebsiella pneumoniae to Escherichia coli. Nature, London 237, $102-103$.

Drozd, J. W. \& PostGate, J. R. (I970). Effects of oxygen on acetylene reduction, cytochrome content and respiratory activity of Azotobacter chroococcum. Journal of General Microbiology 63, 63-73.

Drozd, J. W., Tubb, R. S. \& Postgate, J. R. (1972). A chemostat study of the effect of fixed nitrogen sources on nitrogen fixation, membranes and free amino acids in Azotobacter chroococcum. Journal of General Microbiology 73, 22 I-232.

Eady, R. R., Smith, B. E., Cook, K. A. \& Postgate, J. R. (1972). Nitrogenase of Klebsiella pneumoniae. Biochemical Journal I28, 655-675.

HARDY, R. W. F. \& KNIGHT, E., JUN. (1967). ATP-dependent reduction of azide and hydrogen cyanide by nitrogen-fixing enzymes of Azotobacter vinelandii and Clostridium pasteurianum. Biochimica et biophysica acta 139, 69-90.

Hartman, K. A., Nolan, J. C. \& Amaya, J. (197I). The dependence of the rate of RNase A catalysed hydrolysis of ribosomes and mRNA on the concentration of magnesium and ammonium ions. Biochemical and Biophysical Research Communications 45, I307-1 3 I I.

Hill, S., Drozd, J. W. \& Postgate, J. R. (1972). Environmental effects on the growth of nitrogen-fixing bacteria. Journal of Applied Chemistry and Biotechnology 22, 541-558.

JACQUET, M. \& KePES, A. (1969). The step sensitive to catabolite repression and its reversal by $3^{\prime}-5^{\prime}$ cyclic AMP during induced synthesis of $\beta$-galactosidase in E. coli. Biochemical and Biophysical Research Communications 36, 84-92.

KEPES, A. (1969). Transcription and translation in the lactose operon of Escherichia coli studied by in vivo kinetics. In Progress in Biophysics and Molecular Biology 19, pp. 199-236. Edited by J. A. V. Butler, and D. Noble. Oxford and London: Pergamon Press.

KLUCAS, R. (1972). Nitrogen fixation by Klebsiella grown in the presence of oxygen. Canadian Journal of Microbiology 18, $1845-1850$.

LINDSAY, H. L. (1963). Physiological studies of nitrogen fixation by cells and cell-free extracts of Aerobacter aerogenes. Ph.D. Thesis, University of Wisconsin, Madison, Wisconsin, U.S.A.

Lowry, O. H., Rosebrough, N. J., Farr, A. L. \& Randall, R. J. (195I). Protein measurement with the Folin phenol reagent. Journal of Biological Chemistry r93, 265-275.

LUBIN, M. \& ENNIS, H. L. (1964). On the role of intracellular potassium in protein synthesis. Biochimica et biophysica acta 80, 614-63I.

Mahl, M. C. \& Wilson, P. W. (I968). Nitrogen fixation by cell-free extracts of Klebsiella pneumoniae. Canadian Journal of Microbiology 14, 33-38.

MANDelstam, J. (I962). The repression of constitutive $\beta$-galactosidase in Escherichia coli by glucose and other carbon sources, Biochemical Journal 82, 489-493.

Miskin, R., ZAMIR, A. \& ElSON, D. (1970). Inactivation and reactivation of ribosomal subunits: the peptidyl transferase activity of the 5os subunit of Escherichia coli. Journal of Molecular Biology, 54, 355-378.

PARejko, R. A. \& Wilson, P. W. (1970). Regulation of nitrogenase synthesis by Klebsiella pneumoniae. Canadian Journal of Microbiology $16,68 \mathrm{I}-685$.

Patil, R. B., Pengra, R. M. \& YoCh, D. C. (1967). Effects of nitrogen supplements on nitrogen fixation by Aerobacter aerogenes. Biochimica et biophysica acta $\mathbf{3 6} 6, \mathrm{I}-5$.

Pengra, R. M. \& Wilson, P. W. (1958). Physiology of nitrogen fixation by Aerobacter aerogenes. Journal of Bacteriology 75, $2 \mathrm{I}-25$. 
Postgate, J. R. (1972). The acetylene reduction test for nitrogen fixation. In Methods in Microbiology 6B, pp. 343-556. Edited by J. R. Norris and D. W. Ribbons. London and New York; Academic Press.

Rigano, C. \& Violante, U. (1973). Effect of nitrate, ammonia and nitrogen starvation on the regulation of nitrate reductase in Cyanidium caldarium. Archiv für Mikrobiologie 9o, 27-33.

St John, R. T. \& BRILL, W. J. (1972). Inhibitory effect of methylalanine on glucose-grown Azotobacter vinelandii. Biochimica et biophysica acta 261, 63-69.

Shah, V. K., Davis, L. C. \& BRILL, W. J. (1972). Nitrogenase. I. Repression and derepression of the ironmolybdenum and iron proteins in Azotobacter vinelandii. Biochimica et biophysica acta 256, 498-5I I.

SiPPEL, A. \& HARTMAN, G. (1968). Mode of action of rifamycin on the RNA polymerase reaction. Biochimica et biophysica acta 157, 218-219.

StRANDBERG, G. W. \& WiLSON, P. W. (1968). Formation of the nitrogen-fixing enzyme system in Azotobacter vinelandii. Canadian Journal of Microbiology 14, 25-31.

Streicher, S. L., Gurney, E. G. \& Valentine, R. C. (1972). The nitrogen fixation genes. Nature, London 239, 495-499.

Wilson, P. W., Hull, J. F. \& Burris, R. H. (I943). Competition between free and combined nitrogen in nutrition of Azotobacter. Proceedings of the National Academy of Sciences of the United States of America 29, 289-294.

Yoch, D. C. \& PENGRA, R. M. (1966). Effect of amino acids on the nitrogenase system of Klebsiella pneumoniae. Journal of Bacteriology 92, 61 8-622.

Zumft, W. G., Cretney, W. G., Huang, T. C., Mortenson, L. E. \& Palmer, G. (I972). On the structure and function of nitrogenase from Clostridium pasteurianum w5. Biochemical and Biophysical Research Communications 48, I 525-1532. 